\title{
WIELORAKA REALIZACJA WARUNKÓW DOBORU I JEJ KONSEKWENCJE
}

\begin{abstract}
Streszczenie. Tekst analizuje problem wielorakiej realizacji warunków doboru naturalnego: zmienności, reprodukcji i dziedziczności, przy czym główny nacisk położony zostaje na trzecią z wymienionych cech. Głównym celem prowadzonych analiz jest chęć pokazania, że możliwość wielorakiej realizacji doboru istniałaby nawet wówczas, gdyby pominąć argumenty z zakresu astrobiologii i sztucznego życia i skupić się wyłącznie na analizie genetyki znanych nam form życia.

Tekst omawia również konsekwencje powyższej konkluzji, wskazując jak teza o wielorakiej realizacji warunków doboru wpływa na rozważania o takich zagadnieniach, jak: redukcjonizm w biologii, definiowanie życia, badania dotyczące epigenetyki oraz autonomia biologii. Zaznaczone zostaje także jej znaczenie dla badań nad poziomami selekcji i wielkimi przełomami ewolucji (major transitions in evolution).
\end{abstract}

Słowa kluczowe: wieloraka realizacja, dobór naturalny, definiowanie życia, redukcjonizm, epigenetyka, autonomia biologii

1. Wprowadzenie - dobór naturalny „pod lupą” filozofów. 2.Wieloraka realizacja warunków doboru. 3. Genetyka a wieloraka realizacja. 4. Molekularny redukcjonizm. 5. Wieloraka realizacja, genocentryzm i epigenetyka. 6. Życie. 7. Podsumowanie.

\section{WPROWADZENIE - DOBÓR NATURALNY „POD LUPĄ” FILOZOFÓW}

Dobór naturalny - w świetle współczesnej wiedzy biologicznej - jest podstawowym mechanizmem odpowiadającym za dystrybucje cech i powstawanie złożonych adaptacji w populacjach żywych osobników1. Standardowo przyjmuje się, że ewolucja drogą doboru zajdzie

1 Zob. np. A. Łomnicki, Dobór, dryf i inne czynniki kształtujące częstość genów, w: Zarys mechanizmów ewolucji, red. H. Krzanowska, A. Łomnicki, Warszawa 2002, 156-157, 161-163; P. Godfrey-Smith, Darwinian Populations and Natural Selection, Oxford 2009/2013, 42-43; 
wszędzie tam, gdzie mamy do czynienia ze zbiorem (populacją) jednostek (osobników), które 1) cechują się zmiennością (różnią się między sobą), 2) zdolnością do rozmnażania, 3) dziedzicznością i przynajmniej część zmienności wpływa na szanse przeżycia i reprodukcji. Ostatni warunek to warunek zróżnicowanego dostosowania (ang. fitness). Jeśli wszystkie te warunki są spełnione, to zbiór będzie zmieniał się w czasie - ewoluował ${ }^{2}$. Niektórzy autorzy przyjmują dodatkowe warunki klaryfikujące sytuacje skrajne (np. że populacja nie znajduje się w równowadze ze względu na przepływ genów, co powodowałoby, że nie byłoby ewolucji mimo działania doboru lub że różnice w dystrybucji cech u kolejnych pokoleń nie wynikają z ontogenezy itp.) $)^{3}$.

Dobór naturalny stanowi serce współczesnej teorii ewolucji i dlatego nie jest dziwne, że znalazł się w polu uwagi prężnie rozwijającej się filozofii biologii ${ }^{4}$. Stawiane są pytania metodologiczne o to, czy zasada doboru jest prawem nauki? czy prawo to różni się od praw znanych z fizyki, a jeśli tak, to na czym polegają różnice? Analizowana jest specyfika wyjaśnień selekcyjnych (dystrybutywnego i generatywnego). Stawiane są pytania o sposób mierzenia dostosowania - w szczególności - czy można znaleźć jego uniwersalną miarę, którą można zastosować we wszystkich badanych przypadkach? Czy też przeciwnie jesteśmy

P. Huneman, Sélection, w: Les mondes darwiniens. L'évolution de l'évolution, red. T. Heams, P. Huneman, G. Lecointre, M. Silberstein, Paris 2011, 108; A. Barberousse, S. Samadi, Pourquoi et comment formaliser la théorie de l'évolution, w: Les mondes darwiniens. L'évolution de l'évolution, red. T. Heams, P. Huneman, G. Lecointre, M. Silberstein, Paris 2011, 365.

2 R.C. Lewontin, The Unit of Selection, Annual Review of Ecolology and Systematics 1(1970), 1; J.A. Endler, Natural Selection in the Wild, Princeton 1986, 4; J. Maynard Smith, Problemy biologii, tłum. z ang. M.A. Bitner, Warszawa 1992, 19; M. Ridley, Evolution, Third Edition, Oxford 2003, 74.

3 J.A. Endler, dz. cyt., 4-8.

4 Żeby być zupełnie ścisłym należałoby powiedzieć, iż było to jedno z zagadnień, od badania którego filozofia biologii rozpoczęła swój współczesny renesans. Jednak mimo tego, że od pionierskich prac Davida Hulla czy Elliota Sobera minęło już kilkadziesiąt lat, zainteresowanie doborem nie słabnie. 
skazani na funkcjonowanie (obok siebie) różnych miar dostosowania ${ }^{5}$ ? Pojawiają się też istotne pytania ontologiczne. W ich przypadku granica między filozofią biologii a biologią teoretyczną często zaciera się i nie sposób jednoznacznie wyznaczyć, gdzie kończy się filozofia a zaczyna nauka ${ }^{6}$. Wśród zagadnień ontologicznych pojawia się pytanie o warunki selekcji: czy rzeczywiście ujęcie standardowe (przedstawione powyżej) ujmuje wszystkie istotne warunki? Czy może należałoby uzupełnić je o wskazanie bardziej szczegółowo natury dziedziczenia (jak to ma miejsce w ujęciu replikatorowo-interaktorowym Dawkinsa-Hulla) ${ }^{7}$ ? Czy może przeciwnie należy zlikwidować niektóre wymagania? Na przykład wymóg rozmnażania i dziedziczenia. A jeśli tak, jak wówczas wyjaśnić koncepcję kumulatywnej ewolucjii? Pojawiają się też pytania dotyczące powiązanych z selekcją kategorii: populacji i osobnika. Jeśli chcemy śledzić ewolucyjną zmianę, powinniśmy umieć wyszczególnić

5 Zob. np. P. Huneman, art. cyt.; F. Bouchard, La fitness au-delà des gènes et des organisms, w: Les mondes darwiniens. L'évolution de l'évolution, red. T. Heams, P. Huneman, G. Lecointre, M. Silberstein, Paris 2011; A. Rosenberg, D. McShea, Philosophy of Biology. A Contemporary Introduction, New York - London 2008, 51-63.

6 Na temat relacji filozofii biologii do biologii zob. P. Godfrey-Smith, dz. cyt., 1-4; P. Griffiths, Philosophy of Biology, w: The Stanford Encyclopedia of Philosophy (Winter 2014 Edition), red. E.N. Zalta, http://plato.stanford.edu/archives/win2014/entries/biology-philosophy/.

7 Zob. R. Dawkins, Fenotyp rozszerzony. Dalekosiężny gen, tłum. z ang. J. Gliwicz, Warszawa 2003, 112-130; D. Hull, Individuality and Selection, Annual Review of Ecolology and Systematics 11(1980), 311-332; Na temat krytyki ujęcia replikatorowo-interaktorowego, zob. S. Okasha, Evolution and the Levels of Selection, Oxford 2006/2013, 15-16.

8 Model pokazujący, że rozmnażanie i dziedziczenie mogą być traktowanie jako adaptacje powstałe drogą doboru stworzył Pierrick Bourrat (P. Bourrat, From Survivors to Replicators: Evolution by Natural Selection Revisited, Biology\&Philosophy 29(2014), 517-538). Zaproponował on tym samym rozwiązanie problemu „czystego uboju” - wydawało się, że populacja pozbawiona rozmnażania może jedynie całkowicie wyginąć. Zob. P. Godfrey-Smith, Conditions for Evolution by Natural Selection, Journal of Philosophy 54(2007)10, 494; Tenże, Darwinian Populations and Natural Selection, dz. cyt., 40. Na temat uwag do modelu Bourrata zob. K. Chodasewicz, From survivors to minimal reproducers? The need of one more explanation!, w: Philosophy of (the Living) Nature / Filosofía de la Naturaleza Viviente / Философия (живой) прироgы, red. W. Ługowski, Warszawa 2015, 58-65. 
populację homogenicznych jednostek - czy jednak zawsze jest to możliwe? Oczywiście łatwo policzyć wielokomórkowe zwierzęta cechujące się rozmnażaniem płciowym. Gorzej jednak organizmy klonalne i/ lub modularne 9 . Powstaje też problem $\mathrm{z}$ wyróżnieniem populacji organizmów jednokomórkowych rozmnażających się wyłącznie wegetatywnie ${ }^{10}$. Dlatego niektórzy postulują usunięcie wymagania istnienia populacji, a skupienie się (przynajmniej w niektórych przypadkach) na zróżnicowanym przeżywaniu/eliminacji określonych układów ${ }^{11}$.

Pokrewne zagadnienie stanowi teoretyczno-filozoficzny spór o jednostkę selekcji, czy jest nią tylko gen rozumiany jako jednostka dziedziczenia i/ lub bardzo wąsko jak fragment DNA (tylko tak da się wytlumaczyć bez powoływania się na dobór grupowy - zachowania niekorzystne dla osobników, np. brak rozmnażania robotnic owadów eusocjalnych), czy też może jest nią raczej osobnik (czynnik selekcjonujący nie widzi wszak pojedynczych genów, lecz pewien zespół cech)?12 A może każdy układ spełniający podstawowe warunki doboru? Tradycyjnie np. postulowało się, że wspomniany już dobór grupowy odgrywa niewielką rolę w ewolucji - owszem może zachodzić w bardzo specyficznych warunkach, ale jego realne znaczenie jest niewielkie ${ }^{13}$. Obecnie jednak zwraca się uwagę, że nawet, jeśli tak jest w istocie, to dobór grupowy może być istotny dla wytłumaczenia przeszłych zdarzeń ewolucyjnych, w szczególności tzw. wielkich przełomów ewolucji (major transitions in evolution) ${ }^{14}$. Chodzi o te zdarzenia ewolucyjne, w których jednostki zdolne wcześniej do samo-

9 E. Clarke, Plant Individuality: a Solution's to the Demographer's Dilemma, Biology\&Philosophy 27(2012), 321-361; F. Bouchard, Ecosystem Evolution is About Variation and Persistence, not Population and Reproduction, Biological Theory 9(2014), 382-391.

10 A. Gecow, Informacja dziedziczna i jej kanały (II odcinek szkicu dedukcyjnej teorii życia), Filozofia i Nauka. Studia filozoficzne i interdyscyplinarne 2(2014), 373-374.

11 F. Bouchard, La fitness au-delà des gènes et des organisms, art. cyt., 425-435; Tenże, Ecosystem Evolution is About Variation and Persistence, not Population and Reproduction, art. cyt., 389-390.

12 Zob. np. R. Dawkins, dz. cyt., 131-155; S. Okasha, dz. cyt., 143-172.

13 A. Łomnicki, art. cyt., 203-208.

14 S. Okasha, dz. cyt., 17. 
dzielnego rozmnażania tracą tę zdolność i zaczynają się rozmnażać jako część większej całości. Wśród przykładów można wymienić powstanie komórki eukariotycznej lub organizmów wielokomórkowych ${ }^{15}$. Niektórzy teoretycy argumentują, że aby wytłumaczyć te przeszłe zdarzenia należy przyjąć, że istniały jakieś cechy grup osobników, które były korzystne dla grupy, co spowodowało tendencję w kierunku dalszej integracji ${ }^{16}$.

W kontekście selekcji można oczywiście analizować bardziej tradycyjne problemy ontologiczno-metodologiczne biologii. Jednym z nich jest spór o redukowalność własności biologicznych do własności fizykochemicznych. Spór ten stanowi oś konfliktu dwóch podstawowych współczesnych nurtów filozofii biologii: redukcjonizmu (mechanicyzmu) i organicyzmu. Ten ostatni przyjmuje, że w świecie ożywionym na kolejnych poziomach organizacji pojawiają się własności autentycznie nowe, nie występujące na poziomach niższych i nie będące „prostą sumą” własności składników ${ }^{17}$. (Co ciekawe poglądy te - mimo trwałości sporu o redukcjonizm - rzadko są bronione z nazwy; zamiast na klasyfikacji „-izmów” filozofowie skupiają się raczej na technicznych kwestiach argumentacji). Jednym $z$ typowych argumentów przeciw redukcjonizmowi jest argument $z$ wielorakiej realizacji. Stworzony on został na potrzeby filozofii umysłu, a następnie rozszerzony na problem redukcji nauk szczegółowych do fizyki i polemiki z redukcjonistyczną koncepcją jedności nauki ${ }^{18}$. Głosi on, że określone własności wyższego rzędu mogą być realizowane przez różne własności niższego rzędu. Intuicja jest prosta: łyżka może być drewniana, aluminiowa, plastikowa lub żelazna. W biologii znane są liczne przykłady konwergencji, czyli występowa-

15 J. Maynard Smith, E. Szathmáry, The Major Transitions in Evolution, New York 1995, 6-7, 27-29.

16 S. Okasha, dz. cyt., 218-240.

17 E. Mayr, To jest biologia. Nauka o świecie ożywionym, tłum. z ang. J. Szacki, Warszawa 2002, 29-31.

18 Zob. J. Fodor, Special Sciences (or: The Disunity of Science as a Working Hypothesis), Synthese 28(1974), 97-115; J. Fodor, (przy współpracy N. Blocka), Czym nie sq stany psychiczne?, tłum. z ang. T. Baszniak, w: Filozofia umysłu, wstęp i wybór B. Chwedeńczuk, Warszawa 1995, 59-82. 
nia funkcjonalnie podobnych, ale (zazwyczaj) strukturalnie różnych cech u gatunków $z$ relatywnie niespokrewnionych taksonów ${ }^{19}$. Znanym przykładem są skrzydła owadów, ptaków i nietoperzy. W istocie argument $\mathrm{z}$ konwergencji leżał u podstaw (wraz z tezą o neuroplastyczności i logicznej możliwości stosowania atrybutów mentalnych do artefaktów) koncepcji wielorakiej realizacji ${ }^{20}$. Można jednak spróbować na swój sposób „powrócić do źródeł” i zapytać, czy podstawowe warunki doboru mogą ulegać wielorakiej realizacji?

\section{WIELORAKA REALIZACJA WARUNKÓW DOBORU}

W moich analizach będę posługiwał się standardowym sformułowaniem warunków doboru, choć kwestię wielorakiej realizacji można by stawiać także w kontekście innych ujęć, np. sformułowania replikatorowo-interaktorowego ${ }^{21}$. Myśleniu o wielorakiej realizacji warunków doboru sprzyja niewątpliwie wysoce abstrakcyjny charakter standardowego sformułowania zasady doboru. Warto zwrócić uwagę, że w samej zasadzie nie ma nic na temat szczegółowych mechanizmów dziedziczenia, na temat źródeł zmienności, na temat fizykochemicznej budowy analizowanych obiektów etc. ${ }^{22}$. Co wielu

19 Zob. J. Rafiński, Badanie przebiegu filogenezy, w: Zarys mechanizmów ewolucji, red. H. Krzanowska, A. Łomnicki, Warszawa 2002, 298; L. Marino, Konwergencja złożonych zdolności poznawczych u waleni i naczelnych, w: Psychologia porównawcza, red. W. Pisula, tłum. z ang. M. Michalski, Warszawa 2006, 93-95.

20 J. Fodor, (przy współpracy N. Blocka), Czym nie sq stany psychiczne?, art. cyt., 60-62.

$21 \mathrm{~W}$ istocie zrobił to sam Dawkins, postulując istnienie alternatywnych replikatorów-memów. Zob. R. Dawkins, Samolubny gen, tłum. z ang. M. Skoneczny, Kraków 2007, 241-258; Tenże, Fenotyp rozszerzony. Dalekosiężny gen, dz. cyt., 146-149. W mojej opinii, Dawkins nie był jednak w swoich rozważaniach konsekwentny i jego silny „genocentryzm” (gen podstawową, jeśli nie jedyną jednostką selekcji) wielokrotnie ocierał się o molekularny redukcjonizm (informacja dziedziczna to wyłącznie informacja zapisana w DNA). Patrz paragraf 5. Wieloraka realizacja, genocentryzm i epigenetyka.

22 Szczegółowe uwagi na temat tego, czego nie zawiera zasada doboru, można znaleźć w moim artykule: K. Chodasewicz, Warunki doboru naturalnego a ewolucyjne definicje życia, Filozofia Nauki 24(2016)1, 41-73. 
czytelnikom może wydać się zaskakujące, abstrakcyjny charakter zasady doboru podkreślało wielu biologów ewolucyjnych. Np. Maynard Smith tak pisał o podstawowych warunkach doboru: „Z tych trzech głównych cech rozmnażanie oznacza, że jeden osobnik może dać początek dwóm, a zmienność - że nie wszystkie osobniki są identyczne. Dziedziczność oznacza, że podobne daje początek podobnemu sobie"23.

John Endler wskazywał, że zasada doboru może wykorzystywać różne sposoby dziedziczenia i dotyczyć teoretycznie dowolnych poziomów organizacji biologicznej ${ }^{24}$. Jeszcze bardziej radykalny pod tym względem był Richard Lewontin w swoim słynnym artykule The Units of Selection, gdzie wskazywał, że dobór może dotyczyć zarówno molekuł, organelli, komórek, gamet, osobników, populacji i gatunków ${ }^{25}$. Abstrakcyjny charakter zasady doboru podkreślała też genetyk Eva Jablonka, dla której była to ważna przesłanka dla rozważania różnych kanałów dziedziczenia ${ }^{26}$.

Dla niektórych filozofów abstrakcyjny charakter zasady doboru to może być jednak zbyt mało, aby móc mówić o jego wielorakiej realizacji. Abstrakcja jest typową cechą praw i generalizacji naukowych, nawet tych, które nie zakładają, że własności, których dotyczą, mogą być wielorako realizowane. Kuszące jest myślenie, że aby argumentować na rzecz wielorakiej realizacji doboru należy pokazać, że życie w ogóle jest fenomenem, który może podlegać wielorakiej realizacji. Szczegółowa definicja życia nie jest w tym momencie konieczna ${ }^{27}$. Ważne jest jedynie

23 J. Maynard Smith, Problemy biologii, dz. cyt., 19.

24 J.A. Endler, dz. cyt., 23-26.

25 R.C. Lewontin, art. cyt., 2-16.

26 E. Jablonka, M. J. Lamb, Evolution in Four Dimensions, Cambridge 2005, 11-12.

27 Na temat definiowania życia trwają nieustające spory: na płaszczyźnie metodologicznej dotyczą one sposobu i potrzeby (w tym także w ogóle zasadności) definiowania życia, na płaszczyźnie merytorycznej dotyczą tego, jakie cechy i ich wzajemne powiązania musi wykazywać dany obiekt/fenomen/proces, abyśmy mogli go nazwać życiem. Zob. np. P.L. Luisi, About Various Definitions of Life, Origins of Life and Evolution of Biospheres 28(1998), 613-622; R. Popa, Between Necessity and Probability: Searching for the Definition and Origin 
założenie, że ewolucja drogą doboru jest istotną cechą tego fenomenu. Tutaj jednak teza o wielorakiej realizacji, wspierana przez dziesiątki przykładów konwergencji, obserwowanych na poziomie morfologii, fizjologii i behawioru „rozbija się” o zadziwiającą biochemiczną jedność życia. Nie jest to jednak cios decydujący, gdyż od wielu lat trwają analizy i badania dotyczące szeroko pojętego życia alternatywnego opartego na innej biochemii lub też w ogóle nie mającego „chemicznego umocowania”. Dominują tu dwie dyscypliny: astrobiologia i sztuczne życie (artificial life, ALife). Pierwsza jest następczynią egzobiologii dziedziny, której celem było poszukiwanie życia poza Ziemią. Jednak w przeciwieństwie do egzobiologów astrobiolodzy interesują się także naszą planetą ${ }^{28}$, zwłaszcza środowiskami ekstremalnymi, gdzie, być może, znajdują się jakieś inaczej (pod względem biochemicznym) zbudowane formy życia. Filozof Carol E. Cleland i biolog Shelley D. Copley stworzyły nawet koncepcję biosfery cieni zakładającą, że nasze metody detekcji mikroorganizmów są „ślepe na obcą biochemię”. Tymczasem zupełnie serio możemy rozważać istnienie mikrobów o odmiennej budowie chemicznej ${ }^{29}$. Astrobiolodzy interesują się Ziemią także z innego poważniejszego względu - poszukiwanie życia w kosmosie wymaga wiedzy o tym, jak życie powstaje, a zatem i tego, jak możemy go poszukiwać. Zrozumienie powstania życia na Ziemi może wydatnie w tym dopomóc ${ }^{30}$.

Wróćmy jednak do alternatywnych form życia. Astrobiolodzy budują rozmaite modele teoretyczne „innego” życia. Są wśród nich modele „egzotyczne”, jak np. życie całkowicie oparte na oddziaływaniach

of Life, Berlin - Heidelberg 2004; K. Chodasewicz, Evolution, Reproduction and Definition of Life, Theory of Biosciences 133(2014)1, 39-45; Tenże, Definiować czy nie? Współczesne kontrowersje na temat potrzeby i sposobu definiowania życia, Kosmos. Problemy Nauk Biologicznych 63(2014)4, 501-516. Więcej na ten temat w paragrafie 6. Życie.

28 F. Ferrari, E. Szuszkiewicz, Przedmowa, w: Astrobiologia: poprzez pył kosmiczny do DNA, red. F. Ferrari, E. Szuszkiewicz, Szczecin 2006, 5-6.

29 C.E. Cleland, S.D. Copley, The Possibility of Alternative Microbial Life on Earth, International Journal of Astrobiology 4(2005)3\&4, 166-169.

30 F. Ferrari, E. Szuszkiewicz, art. cyt., 5-6. 
elektromagnetycznych lub nawet oddziaływaniach jądrowych, jak i takie, z którymi jesteśmy bardziej oswojeni, np. życie oparte na związkach krzemu; są też takie, które od znanego życia różnią się tylko nieznacznie, np. wykorzystują niewystępujące u znanych organizmów aminokwasy, zbudowane ze związku o odmiennej chiralności lub wreszcie zastępujące jedne kluczowe pierwiastki innymi (np. fosfor arsenem) ${ }^{31}$.

Można jednak argumentować, że dopóki nie mamy „w ręku” owego alternatywnego życia, czy to ziemskiego, czy to pozaziemskiego, nie możemy mówić o jego wielorakiej realizacji. Co prawda ziemski program astrobiologiczny odniósł pewne sukcesy w postaci znalezienia w kalifornijskim jeziorze Mono bakterii GFAJ-1 zdolnych do zastąpienia fosforu arsenem we wszystkich strukturach molekularnych ${ }^{32}$. Nie jest jednak to życie „w pełni alternatywne”, gdyż organizmy te nie są obligatoryjnymi arsenofilami. Jak się wydaje, teza o biochemicznej jedności życia została przez ten przypadek mocno zachwiana, mimo że jest on nadal przedmiotem szczegółowych analiz i polemik, i wzbudza wiele kontrowersji ${ }^{33}$.

Przypadek sztucznego życia jest inny. Tu w przeciwieństwie do astrobiologii, która dysponuje jednym kontrowersyjnym przypadkiem, mamy do czynienia $z$ wieloma "namacalnymi” przykładami życia i ewolucji implementowanych w innych strukturach. Artificial life (jako dziedzina nauki) posiada trzy główne odmiany: miękkie sztuczne życie, którego obiektem badań są komputerowe (software'owe) implementacje życia, twarde sztuczne życie zajmujące się implementacjami robotycznymi

31 Katalog możliwości zawiera cytowana powyżej praca Cleland i Copley (C.E. Cleland, S.D. Copley, art. cyt., 166-167), jednak bardziej „egzotyczne” hipotezy na temat form życia zawarte są w pracy Irwina i Schulze-Makucha (D. Schultze-Makuch, L.N. Irwin, Life in the Universe. Expectations and Constraints, Berlin - Heidelberg 2008, 149-154).

32 F. Wolfe-Simon, J. Switzer Blum, T.R. Kulp, G.W. Gordon, S.F. Hoeft, J. Pett-Ridge, J.F. Stolz, S.M. Webb, P.K.Weber, P.C.W. Davies, A.D. Anbar, R.S. Oremland, A Bacterium that Can Grow by Using Arsenic Instead of Phosphorus, Science (2010), www.scienceexpress. org./2 December 2010/Page 1/10.1126/science.1197258.

33 Zob. np. P. Rzymski, B. Poniedziałek, Czy życie może być oparte na arsenie? Błędy w badaniach nad bakteriami GFAJ-1, Studia Metodologiczne (2013)30, 145-162. 
oraz mokre sztuczne życie zajmujące się procesami życiopodobnymi z wykorzystaniem alternatywnej biochemii ${ }^{34}$. Wśród opisanych metod implementacji życia najsłynniejsze są oczywiście te software’owe. Jeśli chodzi o ewolucję drogą doboru, to już we wczesnych latach dziewięćdziesiątych Thomas Ray stworzył program Tierra, w którym była ona realizowana. Obecnie istnieje wiele różnych programów używanych przez biologów do badania ewolucji. Wśród nich jest np. program Avida $^{35}$, o którym uważa się, że prawidłowo rekonstruuje ten proces ${ }^{36}$, skoro tak wieloraka realizacja życia, a co za tym idzie doboru, wydaje się być niewątpliwa. Możliwa jest jednak interpretacja alternatywna. Wszystkie opisane przez teoretyków ALife formy życia są jedynie symulacjami! Nie możemy mówić, że jest to autentyczne życie, tak jak komputerowa symulacja huraganu nie jest huraganem ${ }^{37}$. Na płaszczyźnie filozoficznej w sztucznym życiu mamy do czynienia ze sporem analogicznym do sporu w obrębie sztucznej inteligencji między mocną i słabą wersją AI. Podobnie jak można uprawiać artificial intelligence nie twierdząc, że tworzone obiekty są autentycznie inteligentne/świadome, tak samo można uprawiać $A$ Life nie twierdząc, że badane obiekty są żywe. Co więcej, można argumentować, że Christopher Langton - twórca sztucznego życia, a zarazem jego mocnej interpretacji - założył, że życie jest abstrakcyjnym fenomenem, który może być implementowany w wielu różnych „podłożach” ${ }^{38}$. Skoro tak, to sztuczne życie nie może

34 M. Komosiński, Sztuczne życie. Algorytmy inspirowane biologicznie, Nauka (2008)4, 7-8; L.S. Swan, Synthesizing insight: artificial life as thought experimentation in biology, Biology\&Philosophy 24(2009), 687-689.

35 Zob. na ten temat L.S. Swan, art. cyt., 692-694.

36 D. Hang, E. Torng, C. Orifa, T.M. Schmidt, The effect of natural selection on the performance of maximum parsimony, BMC Evolutionary Biology 7(2007), 94.

37 Patrz M.A. Bedau, Philosophical Aspects of Artificial Life, w: Towards a Practice of Autonomous Systems. Proceedings of the First European Conference on Artificial Life, red. P. Bourgine, F.J. Varela, Cambridge 1992, 498.

38 C. Emmeche, Life as an Abstract Phenomenon: is Artificial Life Possible?, w: Towards a Practice of Autonomous Systems. Proceedings of the First European Conference on Artificial Life, red. P. Bourgine, F.J. Varela, Cambridge 1992, 467-468. 
być traktowane jako wsparcie tezy o wielorakiej realizacji życia, gdyż samo taką tezę zakłada ${ }^{39}$.

Musimy więc przyjrzeć się takim własnościom, jak zmienność, dziedziczność czy reprodukcja i-zamiast spekulować na temat alternatywnych form życia - poszukać konkretnych argumentów na rzecz tezy, że podlegają one wielorakiej realizacji. W przypadku rozmnażania nie ma chyba co do tego większych wątpliwości. Możemy mieć do czynienia z typowym dla zwierząt wielokomórkowych rozmnażaniem płciowym, w którym proces generowania nowego osobnika wiąże się jednocześnie z krzyżowaniem (mieszaniem się materiału genetycznego pochodzącego od rodziców). Możemy mieć do czynienia z procesem rozmnażania, który oddzielony jest od procesu krzyżowania (jak ma to miejsce np. u orzęsków). Możemy mieć też do czynienia z rozmnażaniem czysto wegetatywnym $^{40}$. Również od strony fizjologicznej proces rozmnażania obfituje w olbrzymią liczbę możliwości w zależności od analizowanego taksonu. W wielu wypadkach przyszły osobnik przechodzi przez stadium jednokomórkowego „wąskiego gardła” (reproductive bottleneck), jednak nie jest to zawsze konieczne. W przypadku roślin i wielu zwierząt bezkręgowych nowy organizm może wyrastać wprost z organizmu macierzystego (w tym sensie rozmnażanie może być interpretowane jako forma wzrostu, względnie odwrotnie). Rozmaite przypadki, niekiedy skrajnie podważające nasze potoczne intuicje dotyczące rozmnażania,

39 Osobiście nie zgadzam się z tym, że ALife bezwzględnie nie może być traktowane jako autentycznie ożywione (zob. K. Chodasewicz, Ożywione artefakty? Analiza wybranych argumentów przeciwko sztucznemu życiu, Studia Philosophica Wratislaviensia 10(2015)1, 73-74), zarazem jednak wskazywałem już wcześniej na nieprzekonujący charakter argumentu na rzecz wielorakiej realizacji życia, który za punkt wyjścia brałby artificial life (zob. K. Chodasewicz, Wieloraka realizacja i życie, Filozofia i Nauka. Studia filozoficzne i interdyscyplinarne 1(2013), 131-133).

40 A. Gecow, Algorytmy ewolucyjne i genetyczne, ewolucja sieci złożonych i modele regulacji genowej a mechanizm darwinowski, Kosmos. Problemy Nauk Biologicznych 58(2009)3-4, 430. 
omawia Peter Godfrey-Smith ${ }^{41}$. Wyróżnił on trzy rodzaje reproducerów (czyli zdolnych do rozmnażania jednostek). Są to:

1) kolektywni reproducerzy (collective reproducers) - to organizmy, których części same potrafią się rozmnażać, zazwyczaj w oparciu o własne zasoby i niekoniecznie w wyniku skoordynowanej aktywności całości (chodzi głównie o typowe organizmy modularne, jak większość roślin, koralowców itp.),

2) prości reproducerzy (simple reproducers) - to organizmy, które rozmnażają się w wyniku aktywności osobnika jako całości i posiadające całą niezbędną do tego „maszynerię”; konstytuują „paradygmatyczny typ” rozmnażania się.

3) „rusztowaniowi” repreducerzy (scaffolded reproducers) - to twory nie posiadające całej niezbędnej do rozmnażania „maszynerii”, np. wirusy, wiroidy ${ }^{42}$.

Powyższy podział nie jest jedynym możliwym. Godfrey-Smith pokazuje, że możemy rozważać różnice dotyczące rozmnażania w kontekście takich parametrów, jak wspomniane już „wąskie gardło” między pokoleniami (bottleneck) czy rozdzielenie linii somy i linii komórek płciowych (ostre u kręgowców, a znaczenie bardziej rozmyte u wielu innych taksonów) ${ }^{43}$. Nie chcę tu wchodzić w szczegóły jego analiz, pragnę jedynie zaznaczyć, że rozmnażanie - rozumiane jako pewna ogólna zdolność do tworzenia obiektów potomnych - może być realizowana na wiele różnych sposobów. Jak już wspomniałem, nie wydaje się to być twierdzeniem kontrowersyjnym, jeśli tylko wykroczymy w naszych analizach poza świat zwierząt wyższych.

$\mathrm{Na}$ pozór inaczej rzecz się ma ze zmiennością i dziedzicznością. Co prawda zmienność może powstawać w wyniku różnych oddziaływań środowiska, jednak odnośnie do ewolucji interesuje nas tzw. dziedziczna zmienność, czyli takie zmiany, które mogą być przekazane przyszłym

41 P. Godfrey-Smith, Darwinian Populations and Natural Selection, dz. cyt., 70-81.

42 Tamże, 87-88.

43 Tamże, 91-100. 
pokoleniom. Prowadzi to do problemu zapisu i przekazywania informacji dziedzicznej, w którym kwestie zmienności i dziedziczności są ze sobą mocno powiązane ${ }^{44}$. O ile więc rozmnażanie może być realizowane przez wiele różnych procesów fizjologicznych, to dziedziczenie wydaje się cechować zdumiewającą jednością. U większości znanych form życia informacja dziedziczna zawarta jest w DNA. Zaskakująco jednorodny jest także sposób zapisu tej informacji - określany mianem kodu genetycznego. Danym trójkom nukleotydów odpowiada określony aminokwas (np. CAC koduje histydynę) ${ }^{45}$. Stąd kolejność nukleotydów w DNA koduje kolejność aminokwasów w białku. Czy więc w obszarze dziedziczenia możemy poszukiwać jakichś argumentów na rzecz wielorakiej realizacji? Odpowiedź jest twierdząca. Po pierwsze, powinniśmy zwrócić uwagę na to, że współczesne badania nie zostawiają genom (rozumianym jako odcinki DNA) „wyłączności” na przekazywanie informacji dziedzicznej. Obecnie znanych jest wiele epigenetycznych kanałów jej przekazu - wśród mechanizmów molekularnych ${ }^{46}$ można wymienić m.in.:

44 Oczywiście fenotypowa zmienność może być generowana na setki sposobów. Osobniki posiadające dane cechy mogą też mieć zróżnicowane szanse przeżycia i reprodukcji, jednak nie będziemy mieć do czynienia z doborem naturalnym, jeśli wspomniane zmiany nie będą zmianami dziedzicznymi. A. Łomnicki, art. cyt., 157.

45 Zob. np. H. Krzanowska, Zapis informacji genetycznej, w: Zarys mechanizmów ewolucji, red. H. Krzanowska, A. Łomnicki, Warszawa 2002, 26.

46 Świadomie piszę tu wyłącznie o mechanizmach molekularnych, bowiem przy bardzo szerokim rozumieniu pojęcia dziedziczenia można utrzymywać, że dla doboru (ściśle: dla zaistnienia dziedzicznej zmienności) może być ważna także informacja przekazywana w drodze behawioralnej (naśladownictwo) i symbolicznej. Wyobraźmy sobie np. populację jakiegoś gatunku, w której istnieją różne sposoby zdobywania pokarmu. Sposoby te są przekazywane na linii matka-potomstwo w drodze naśladownictwa. Powoduje to wyraźną różnicę w zachowaniu osobników, która (załóżmy np. że jeden sposób jest mniej efektywny od drugiego) wpływa na szanse przeżycia i reprodukcji działających wg nich osobników. Skutkuje to zmianą frekwencji cech w populacji (upowszechnienie się sposobu bardziej efektywnego). Zagadnienia te analizują Jablonka i Lamb (E. Jablonka, M.J. Lamb, dz. cyt., 153-227). Są to jednak kwestie bardzo kontrowersyjne, a z tego względu - podobnie jak w przypadku sztucznego życia - niemające odpowiedniej siły przekonywania względem analizowanej tu tezy. 
1) metylację DNA - polega ona na tym, że grupy metylowe przyłączają wiązaniami kowalencyjnymi do DNA i powodują zmianę w ekspresji genów; nie jest do końca jasne, w jaki sposób następuje ich rekonstrukcja po wytworzeniu się gamet, ale istnieją dowody na to, że mogą się one utrzymywać przez wiele pokoleń; metylacja DNA może powodować znaczące zmiany fenotypowe rzutujące na szanse przetrwania i reprodukcji ${ }^{47}$;

2) dziedziczenie „matrycowe” (structural templating) - polega na tym, że określone struktury molekularne służą jako matryca dla wytworzenia nowych struktur, które przy braku ich obecności nie tworzą się spontanicznie; za ojca tej idei uważa się często Toma Cavaliera-Smitha, który wprowadził pojęcie „membranomu”, dla określenia tego, że niektóre błony komórkowe również niosą ze sobą istotną informację dziedziczną, która nie jest zawarta w DNA; badania na pierwotniakach z rodzaju Paramecium wskazują, że zmiany w obrębie tzw. korteksu (struktury zawierającej m.in. układ rzęsek), także te wprowadzone eksperymentalnie, są dziedziczone w ciągu wielu pokoleń (i to nawet wtedy, gdy mamy do czynienia z krzyżowaniem się); choć dziedziczenie matrycowe odnosiło się początkowo do błon komórkowych, to jednak do tej grupy można zaliczyć dziedziczenie za pośrednictwem prionów (białka o zmienionej konformacji są przekazywane przez cytoplazmę w czasie podziału komórek), które u niektórych grzybów (np. Saccharomyces cerevisiae) powoduje istotne efekty fenotypowe ${ }^{48}$;

3) dziedziczenie przez tzw. pętle metaboliczne - polega na tym, że określone produkty szlaków metabolicznych kodowane przez określone geny mogą regulować aktywność tychże genów; powoduje to, że np. produkt ekspresji danego genu może działać

47 E. Jablonka, M.J. Lamb, Transgenerational Epigenetic Inheritance, w: Evolution - the Extended Synthesis, red. M. Pigliucci, G.B. Müller, Cambridge - London 2014, 147-150.

48 Tamże, 147. Zob. też E. Jablonka, M. J. Lamb, Evolution in Four Dimensions, dz. cyt., $120-124$. 
jako aktywator swojej własnej ekspresji; ponieważ produkt jest obecny w cytoplazmie, jest przekazywany kolejnym pokoleniom w wyniku podziału komórek (rozmnażanie bezpłciowe) lub przez cytoplazmę gamet ${ }^{49}$.

Oczywiście w podanych powyżej przypadkach (poza przypadkiem 2) można powiedzieć, że mowa o dodatkowych czynnikach, które zmieniają ekspresję genów. To oczywiście prawda. Jednak przypadki te pokazują, że geny nie przekazują całej informacji dziedzicznej, która może mieć efekt fenotypowy. Biolodzy mogą się spierać o rzeczywiste znaczenie tych procesów w ewolucji znanych nam organizmów, jednak fakt ich istnienia jest niepodważalny i świetnie koresponduje $z$ tezą o wielorakiej realizacji warunków doboru.

Kolejnego argumentu dostarczają wirusy, u których informacja dziedziczna zawarta jest w RNA ${ }^{50}$. Wirusy należą do zbioru tzw. przypadków granicznych - zbioru obiektów, co do których nie jest jasne, czy należy uważać je za ożywione. Istotnie wielu uczonych neguje klasyfikowanie ich jako żywych ${ }^{51}$. Nie ma jednak wątpliwości, że twory te mogą podlegać ewolucji drogą doboru naturalnego, a skoro tak, stanowią one namacalny przykład na to, że przekaz informacji dziedzicznej może być realizowany wielorako.

\section{GENETYKA A WIELORAKA REALIZACJA}

Można jednak argumentować, że nawet jeśliby nie było ani dziedziczenia epigenetycznego, ani przypadków z zapisem informacji dziedzicznej w RNA, teza o wielorakiej realizacji warunków doboru pozostawałby możliwa do obrony. Wyrażając się ściśle: do

49 E. Jablonka, M.J. Lamb, Transgenerational Epigenetic Inheritance, art. cyt., 145-146.

50 Zob. np. H. Krzanowska, art. cyt., 22-23.

51 P.L. Luisi, Autopoiesis. A Review and a Reappraisal, Naturwissenschaften 90(2003), 51-52;

P. Forterre, Defining Life: The Virus Viewpoint, Origins of Life and Evolution of Biospheres, 40(2010), 156; S. Pennazio, Viruses: are they living entities?, Theoretical Biology Forum (Formerly »Rivista di biologia - biology forum«) (2011)1, 45, 53-54. 
obrony pozostawałaby teza o możliwości wielorakiej realizacji dziedziczenia. Zastanówmy się przez chwilę, co trzeba by wykazać, aby uzasadnić tezę przeciwną. Należałoby mianowicie powiedzieć, że istnieje jedno-jednoznaczna odpowiedniość między określonymi trójkami nukleotydów, a odpowiadającymi im aminokwasami i że owa jedno-jednoznaczna odpowiedniość determinowana jest przez prawidłowości o charakterze fizykochemicznymi. Dane dostarczane przez biologię molekularną wydają się jednak świadczyć na rzecz tezy przeciwnej. Wynika to $\mathrm{z}$ faktu, że droga od zapisu informacji w DNA do białka jest procesem wieloetapowym i mającym określony skutek tylko w odpowiednio zorganizowanym systemie. Jednak sama ta organizacja kodowana jest przez geny w DNA i jako taka nie ma charakteru niezmiennego.

Przyjrzyjmy się powyższemu zagadnieniu w detalach. Wybitny bio$\log$ ewolucyjny John Maynard Smith opisywał wspomniany fenomen następująco: „Co na razie jest ważne, to to, że natura kodu (np. fakt, że GCC koduje glicynę) zależy od istnienia cząsteczek tRNA $z$ antykodonem CCG i doczepioną cząstką glicyny na drugim końcu. Jak to się dzieje? Cząsteczki tRNA same są kopiami genów w DNA w jądrze. Kiedy powstają po raz pierwszy, nie mają doczepionej cząstki glicyny. Doczepienie to jest dokonywane w cytoplazmie przez specjalne białko, które jest w stanie rozpoznać zarówno cząstki glicyny, jak i zakończenie cząstki tRNA, i połączyć je razem. Białka działające w ten sposób nazywane są »enzymami« (...). Oczywiście enzymy te są także kodowane przez gen w DNA w jądrze.

Tak więc w cytoplazmie znajduje się wiele różnych rodzajów cząstek tRNA, każdy rodzaj oznaczony przez dwie »etykietki«: w jednym miejscu antykodon (który łączy się w pary z kodonem w przekazie), a na drugim końcu miejsce dla aminokwasu (który jest rozpoznawany przez enzym posiadający ten określony aminokwas). Natura kodu (czyli, na przykład, że GCC koduje glicynę) zależy całkowicie od tego, który antykodon i jakie miejsce przyczepu występują razem na cząstce tRNA. Wynika z tego, że istnieją pewne rodzaje zmian w DNA jądrowym (takie 
zmiany nazywane są »mutacjami« (...), które będą powodowały zmianę w kodzie. Mogłoby to być spowodowane przez zmianę genetyczną, która zmieniałaby antykodon cząsteczki tRNA bez zmiany miejsca przyczepu dla aminokwasu (lub odwrotnie); takie mutacje pojawiają się rzadko"52.

A zatem odpowiedniość między określonymi trójkami nukleotydów a aminokwasami nie jest dana raz na zawsze i nie wynika $z$ jakiś szczególnych fizykochemicznych własności określonych trójek (określone kodony nie są np. katalizatorami albo substratami reakcji syntezy określonych aminokwasów). Zaskakująca jednorodność kodu musi być wytłumaczona argumentami historyczno-systemowymi.

W Problemach biologii (wydanych oryginalnie w 1986 roku) Maynard Smith stwierdził, że jedność kodu należy wytłumaczyć pochodzeniem od wspólnego przodka ${ }^{53}$, zaś brak obserwowanych zmian w kodzie tłumaczy się tym, że każda zmiana tak podstawowego elementu organizacji systemu żywego byłaby prawdopodobnie letalna ${ }^{54}$. Teza podobna została powtórzona przez Maynarda Smitha i Eörsa Szatmárego w Tajemnicach przetomów erwolucji. Obaj autorzy pisali wówczas w ten sposób: „Kod jest tak uniwersalny, że można domniemywać, iż całe życie na Ziemi ma jedno, jedyne wspólne pochodzenie. Alternatywne wytłumaczenie tej powszechności musiałoby zakładać, że istnieją jakieś chemiczne przyczyny, dla których AAA musi kodować lizynę, AUG - metioninę i tak dalej. Nadal dyskutuje się, czy istnieje jakiś wyraźny chemiczny sens poszczególnych przypisań kodon-aminokwas, lecz na ogół wszyscy są zgodni, że nawet jeśli istnieją pewne powinowactwa chemiczne,

52 J. Maynard Smith, Problemy biologii, dz. cyt., 41.

53 Stwierdzenie to zakłada, że w przeszłości mogły istnieć inne warianty kodu, które się jednak nie upowszechniły. (Albo wyposażone w nie organizmy „przegrały ewolucyjny wyścig" z tymi wyposażonymi w kod obecny lub też kod obecny stał się w pewnym momencie jedynym dostępnym na skutek jakiś zdarzeń losowych).

54 J. Maynard Smith, Problemy biologii, dz. cyt., 40. 
to są one dalece niewystarczające. Uniwersalność kodu musi wynikać ze wspólnego pochodzenia" ${ }^{25}$.

Cytowane Tajemnice przetomów erwolucji (tytuł oryginału: The origins of life. From the birth of life to the origin of language) stanowia swego rodzaju popularnonaukowe streszczenie wpływowego dzieła Maynarda Smitha i Szatmárego The Major Transitions in Evolution. Warto więc zaznaczyć, że w tym ostatnim dziele obaj autorzy są nieco bardziej wstrzemięźliwi. Piszą więc, że oprócz wyjaśnienia historycznego, istnieje koncepcja stereochemiczna wskazująca na możliwość istnienia w przeszłości pewnego powinowactwa chemicznego między trójkami nukleotydów a danymi aminokwasami. Określone aminokwasy miałyby pasować do określonych kodonów na zasadzie „zamka i klucza”"56. Jeśli teoria ta jest poprawna, czy oznacza to unicestwienie tezy o wielorakiej realizacji warunków doboru (tu: warunku dziedziczenia)? Odpowiedź jest negatywna, a jest tak $z$ dwóch powodów. Po pierwsze, pierwotny kod miałby być jednak inny niż obecnie ${ }^{57}$ - oznacza to, że ewolucja kodu jednak jest możliwa, a powinowactwo stereochemiczne nie wyczerpuje złożonej relacji między kodonami a aminokwasami. Pod drugie zaś, współczesna organizacja systemu dziedziczenia teoretycznie dopuszcza możliwość zmiany relacji kodon - aminokwas. Furtka do wielorakiej realizacji pozostaje więc otwarta.

Jak się okazuje, nie jest to możliwość czysto teoretyczna - kod genetyczny faktycznie nie jest bezwyjątkowy. Wyjątki występują np. w DNA mitochondrialnym ssaków, grzybów Neurospora i kukurydzy, w rodzaju Paramecium, a także u bakterii Mycoplasma ${ }^{58}$. Biologów może interesować, czy różnice te są reliktami przeszłości, czy też, przeciwnie,

55 J. Maynard Smith, E. Szathmáry, Tajemnice przełomów ewolucji, tłum. z ang. M. Madaliński, Warszawa 2000, 58.

56 J. Maynard Smith, E. Szathmáry, The Major Transitions in Evolution, dz. cyt., 93.

57 Tamże, 81-95. Zob. też J. Maynard Smith, E. Szathmáry, Tajemnice przełomów ewolucji, dz. cyt., 55-59.

58 J. Maynard Smith, E. Szathmáry, The Major Transitions in Evolution, dz. cyt., 81-83; H. Krzanowska, art. cyt., 27. 
są to zmiany powstałe stosunkowo niedawno ${ }^{59}$. $\mathrm{Z}$ punktu widzenia niniejszego artykułu nie jest to jednak zagadnienie istotne - ważne, że możliwość wielorakiej realizacji kodu, a tym samym wielorakiej realizacji dziedziczenia jest zachowana.

\section{MOLEKULARNY REDUKCJONIZM}

Teza o wielorakiej realizacji warunków doboru ma liczne konsekwencje. Argument $\mathrm{z}$ wielorakiej realizacji jest uważany za jeden $\mathrm{z}$ najlepszych argumentów przeciw redukcjonizmowi ${ }^{60}$. $Z$ tego względu teza o wielorakiej realizacji warunków doboru w sposób miażdżący uderza w koncepcje redukcjonistyczne w biologii i filozofii biologii, a także w mocno z nimi związane poglądy genocentryczne.

Aby zrozumieć znaczenie tego uderzenia, należy pokrótce przedstawić wagę wspomnianych poglądów we współczesnym myśleniu o bycie ożywionym. Jak powszechnie wiadomo, jednym z podstawowych problemów oryginalnej koncepcji Karola Darwina był problem ze wskazaniem wiarygodnych mechanizmów dziedziczenia ${ }^{61}$. Darwin zaproponował koncepcję dziedziczenia opartego na uśrednianiu się cech potomstwa i rodziców, której „molekularną podbudowę” miała stanowić koncepcja gemmul - małych cząstek, które miały zstępować z każdej części ciała do komórek płciowych (pangenetyczna koncepcja dziedziczenia) ${ }^{62}$. Dodatkowo Darwin dopuszczał - podobnie jak wcześniej Lamarck - dziedziczenie cech nabytych ${ }^{63}$. Zmiana w organizmie rodzica mogła wpłynąć na gemmule i doprowadzić do pojawienia się

59 Tamże, 27.

60 Zob. np. A. Grobler, Metodologia nauk, Kraków 2006, 244.

61 A. Łomnicki, Spotkanie teorii Darwina z genetyką, Kosmos. Problemy Nauk Biologicznych, 58(2009)3-4, 315; K. Łastowski, Dwieście lat idei ewolucji w biologii. Lamarck - Darwin - Wallace, Kosmos. Problemy Nauk Biologicznych, 58(2009)3-4, 264; B.-O. Küppers, Geneza informacji biologicznej. Filozoficzne problemy powstania życia, tłum. z niem. W. Ługowski, Warszawa 1991, 169-170.

62 E. Jablonka, M.J. Lamb, Evolution in Four Dimensions, dz. cyt., 14-16.

63 Tamże, 15; J. Maynard Smith, Problemy biologii, dz. cyt., 21-27. 
danej cechy u potomstwa. Pierwszy element rozumowania Darwina został szybko poddany dotkliwej krytyce. Inżynier Fleeming Jenkins pokazał, że jeśli dziedziczenie ma przebiegać tak, jak postulował to Darwin, to dobór naturalny nie może efektywnie działać ${ }^{64}$. „Drugi filar" dziedziczenia koncepcji Darwina został poddany krytyce przez Augusta Weismanna (skądinąd wybitnego biologa ewolucyjnego i zwolennika darwinizmu). Wykazał on, że dziedziczenie cech nabytych nie może zachodzić - np. syn kowala nie dziedziczy potężnych mięśni swego ojca. Informacja dziedziczna przekazywana jest jedynie przez linię komórek płciowych (a nie przez linię somy) i tylko przypadkowe zmiany w linii płciowej mogą prowadzić do dziedzicznych zmian ${ }^{65}$. Weismann stworzył też podwaliny myślenia, że dziedziczenie związane jest $\mathrm{z}$ substancją zawartą w jądrze komórkowym, i że w procesie tworzenia komórek płciowych zyskują one jedynie połowę owego materiału (inaczej ilość materiału dziedzicznego stale by wzrastała) ${ }^{66}$. Problem $\mathrm{z}$,wypełnieniem” darwinizmu przez wiarygodną teorię dziedziczenia był poniekąd paradoksalny, gdyż już w czasach Darwina czeski mnich Georg Mendel stworzył popartą badaniami empirycznymi koncepcję czynnika dziedzicznego. Prace Mendla przeszły wówczas bez echa. Ponowne odkrycie praw Mendla przez Hugo de Vriesa, Carla Corrensa i Ericha von Tschemarka doprowadziło jednak do powstania wątpliwości, czy można pogodzić je z darwinowską teorią ewolucji. Np. wspomniany de Vries był mutacjonistą, tj. sądził, że zmiany ewolucyjne zachodzą nagle i od razu przebudowują konstrukcję organi$\mathrm{zmu}^{67}$. Dopiero w latach 40. XX wieku, dzięki pracom S. Wrighta, J.B.S. Haldane’a i R. Fishera, udało się pokazać, że między genetyką

64 B.-O. Küppers, dz. cyt.; A. Łomnicki, Spotkanie teorii Darwina z genetyka, art. cyt., 315. 65 J. Maynard Smith, Problemy biologii, dz. cyt., 26-28; E. Jablonka, M. J. Lamb, Evolution in Four Dimensions, dz. cyt., 16-21.

66 Tamże, 17.

67 E. Jablonka, M.J. Lamb, Evolution in Four Dimensions, dz. cyt., 23-27; A. Łomnicki, Spotkanie teorii Darwina z genetyką, art. cyt., 315-316. 
a teorią doboru nie ma sprzeczności ${ }^{68}$. Tak narodziła się genetyka populacyjna - dziedzina badająca zmiany frekwencji genów w populacji. Prace wspomnianych badaczy uzupełnione o badania (m.in.) Ernsta Mayra, George’a Simpsona oraz George’a Stebbinsa zaczęto wkrótce określać mianem Nowoczesnej Syntezy (Modern Synthesis) ${ }^{69}$. Jednocześnie rozwijały się badania biochemiczne i molekularne pozwalające poznać substancjalne podstawy dziedziczenia - materialną naturę owych genów, które w pracach stojących u podstaw Nowoczesnej Syntezy były raczej konstruktem teoretycznym. Kluczowe były tu prace Thomasa Hunta Morgana i jego szkoły, które przerzuciły twardy pomost między bytem teoretycznym, jakim był „czynnik dziedziczny” Mendla, a budową komórki ${ }^{70}$. Geny miały znajdować się w chromosomach w jądrze komórkowym, z których połowa przekazywana jest do każdej komórki płciowej w procesie podziału mejotycznego. Bardzo dobrze korespondowało to z założeniami Mendla o istnieniu w każdej gamecie jednego $\mathrm{z}$ dwóch par alleli (odmian danego genu) obecnych $\mathrm{w}$ organizmie rodzica, oraz z wcześniejszymi propozycjami Weismanna, dotyczącymi podziału plazmy dziedzicznej ${ }^{71}$. W latach pięćdziesiątych zgodzono się ostatecznie, że substancją przenoszącą informację dziedziczną jest zawarty w chromosomach kwas deoksyrybonukleinowy (DNA). Dalszy rozwój wypadków jest powszechnie znany. Dzięki pracom Jamesa Watsona, Francisa Cricka, Maurice'a Wilkinsa i Rosalind Franklin poznano strukturę DNA. Kolejnym krokiem było wprowadzenie tzw. centralnego dogmatu biologii molekularnej (Crick) o niemożliwości transkrypcji informacji z białek na DNA. Był to odpowiednik koncepcji

68 A. Łomnicki, Spotkanie teorii Darwina z genetyka, art. cyt., 316; M. Pigliucci, G.B. Müller, Elements of an Extended Evolutionary Synthesis, w: Evolution - the Extended Synthesis, red. M. Pigliucci, G.B. Müller, Cambridge - London 2014, 6.

69 Tamże, 7-8. Zob. też E. Jablonka, M. J. Lamb, Evolution in Four Dimensions, dz. cyt., 28- 29.

70 Tamże, 27-30.

71 Tamże, 30-31. 
Weismanna na poziomie molekularnym ${ }^{72}$. Wreszcie poznano zasady funkcjonowania kodu genetycznego. Geny okazały się odcinkami DNA. Jak określa to Eva Jablonka, nastąpiła całkowita „supremacja DNA”, jeśli chodzi o myślenie o dziedziczności ${ }^{73}$.

Wspomniany ciąg wydarzeń położył podwaliny pod możliwość nowego sposobu myślenia o koncepcji doboru - naturalna selekcja nie byłaby możliwa, gdyby nie takie-a-takie własności biochemiczne związków budujących organizmy żywe. Oczywiście powyższa interpretacja nie jest bezsensowna i nie byłoby w niej nic groźnego, gdyby miała dotyczyć jedynie historii życia na Ziemi. Wielu naukowców potraktowało jednak cechy historycznie kontyngentne jako wystarczające i konieczne dla doboru, i zaczęło głosić tezę, że dobór jest wynikiem szczególnych własności makromolekuł, w szczególności DNA. W następujący sposób wypowiadał się na ten temat Bernd-Olaf Küppers (wspólpracownik twórcy teorii hipercykli Manfreda Eigena): „Autoreprodukcja, metabolizm i zmienność są zatem inherentnymi własnościami pewnej jednolitej klasy substancji, a mianowicie kwasów nukleinowych; znaczy to, że wszystkie wymienione wyżej niezbędne warunki rozwoju systemów żywych są spełnione już na przedkomórkowym poziomie ewolucji molekularnej.

Możemy teraz wyprowadzić z chemicznych własności kwasów nukleinowych następującą operacyjną definicję »autoreplikacji« (...). W kontekście tej definicji fenomen autoreplikacji nie może być już traktowany jako nieredukowalna własność systemów żywych, lecz jako ogólna cecha kinetyki reakcji kwasów nukleinowych, która podpada pod fizyczne pojęcie autokatalizy" ${ }^{\prime 4}$.

Podobne poglądy wyrażał wcześniej wybitny biolog molekularny Jacques Monod, utożsamiający obecność teleonomii układów żywych

72 Zob. J. Maynard Smith, Problemy biologii, dz. cyt., 41-42.

73 E. Jablonka, M. J. Lamb, Evolution in Four Dimensions, dz. cyt., 30-33; zob. też A. Gecow, Ewa Jabłonka i Lamarck, Kosmos. Problemy Nauk Biologicznych 59(2010)1-2, 28-31.

74 B.-O. Küppers, dz. cyt., 140-141. 
z obecnością białek enzymatycznych, zaś reprodukcyjnej inwariancji z obecnością $\mathrm{DNA}^{75}$. Oba poglądy są przykładami radykalnego redukcjonizmu molekularnego w filozofii biologii. Oczywiście poglądy redukcjonistyczne (mechanistyczne, fizykalistyczne) i antyredukcjonistyczne (początkowo witalistyczne, następnie holistyczne/organicystyczne) spierały się w myśleniu o życiu poprzez wieki ${ }^{76}$, jednak dzięki odkryciom biologii molekularnej i genetyki pierwsze z nich zyskały, jak się wydawało, niezwykle twardą, niemożliwą do obalenia podbudowę.

$\mathrm{Z}$ poglądami redukcjonistycznymi dobrze współgrały poglądy genocentryczne, reprezentowane między innymi przez Williama Hamiltona i Richarda Dawkinsa. Zgodnie z nimi, gen jest nie tylko jednostką dziedziczenia, ale także podstawową jednostką selekcji, w interesie której istnieją adaptacje organizmów $w^{77}$. Podejście genocentryczne teoretycznie nie musi być tożsame $z$ molekularno-redukcjonistycznym ${ }^{78}$. Pod tym względem np. w koncepcji Dawkinsa istnieje silna ambiwalencja. $Z$ jednej strony gen jest definiowany funkcjonalnie, jako jednostka doboru. $\mathrm{Z}$ drugiej jednak strony wspomniany autor wciąż pisze o genach jako o odcinkach DNA ${ }^{79}$. Można więc przyjąć, że nawet jeśli gen w sensie ewolucyjnym nie jest tożsamy z cistronem (fragmentem DNA kodującym określone białko) i ma częściowo rozmyte granice, to i tak zawsze musi to być odcinek DNA. Bardzo łatwo stąd przejść do tezy, że selekcja

75 Zob. np. J. Monod, Le hasard et la nécesité. Essai sur la philosophie naturelle de la biologie moderne, Paris 1970, 59, 118. „Reprodukcja inwariantna” (reproduction invariante / invariance) jest pojęciem z obszaru monodowskiej koncepcji życia. Oznacza zdolność układów żywych do powielania się i dziedziczenia, rozumianego jako przekazanie niezmienionej informacji strukturalnej potomstwu. Zob. J. Monod, dz. cyt., 25-32. Warto nadmienić, że proponowana przez Monoda redukcjonistyczna wizja życia była silnie krytykowana przez polskiego biologa Adama Urbanka, który wskazywał, że kwasy nukleinowe nie są w stanie spełnić przypisywanej im przez Monoda roli bez uwzględnienia działania określonych form doboru naturalnego, a zatem bez presji selekcyjnej środowiska. Zob. A. Urbanek, Rewolucja naukowa w biologii, Warszawa 1973, 74-87.

76 Zob. np. E. Mayr, To jest biologia. Nauka o świecie ożywionym, dz. cyt., 19-31.

77 Zob. R. Dawkins, Fenotyp rozszerzony. Dalekosiężny gen, dz. cyt., 112-130.

78 Zob. E. Jablonka, M. J. Lamb, Evolution in Four Dimensions, dz. cyt., 36.

79 Zob. np. R. Dawkins, Fenotyp rozszerzony. Dalekosiężny gen, dz. cyt., 119n. 
to proces, wynikający z własności DNA, a prawa biologii ewolucyjnej redukują się do praw biologii molekularnej.

Argument z wielorakiej realizacji warunków doboru pokazuje, że nie jest to prawda. Co ważne, waga tego argumentu pozostaje w mocy nawet, jeśli pominiemy wszelkie rozważania na temat alternatywnych kanałów dziedziczenia i skupimy się wyłącznie na "standardowych” mechanizmach przekazywania informacji dziedzicznej.

\section{WIELORAKA REALIZACJA, GENOCENTRYZM I EPIGENETYKA}

Molekularny redukcjonizm i genocentryzm to poglądy rzutujące na wiele dziedzin współczesnego myślenia zarówno w obrębie samej biologii, jak i jej metodologii oraz filozofii tej dyscypliny. Problemy te były szeroko opisywane i nie będę ich tu szeroko referował. Ograniczę się do jednego przypadku, który pokazuje, dlaczego polemika z powyższymi poglądami była do niedawna niezwykle utrudniona. Wspomniane już wypełnienie koncepcji Darwina genetyczną treścią doprowadziło do powstania z pozoru niewinnego przekonania, że cecha dziedziczna, to cecha zapisana w genach. Jak już zaznaczałem, wzmocnienie dowodu Weismanna na brak dziedziczenia cech nabytych zostało dostarczone przez Cricka. Sformułował on hipotezę, zwaną centralnym dogmatem biologii molekularnej, która głosiła, że informacja dziedziczna jest przekazywana z DNA na RNA a następnie do białek i tylko w tym kierunku. Hipoteza ta została następnie potwierdzona, choć wkrótce też odkryto, że możliwe jest przekazywanie informacji z RNA do DNA. Nie miało to jednak decydującego znaczenia dla dogmatu, gdyż nadal nieznane są mechanizmy mogące powodować trwałe modyfikacje DNA pod wpływem zmian w białkach ${ }^{80}$. Pozornie obalało to wszelkie spekulacje na

80 „Chociaż zwykle informacja przechodzi od DNA do RNA, to może wędrować również w odwrotnym kierunku. Zjawisko to cytuje się czasami jako zaprzeczenie centralnego dogmatu, ale jest to nieporozumienie". J. Maynard Smith, Problemy biologii, dz. cyt., 41. 
temat innych kanałów dziedziczenia. Nastąpiło subtelne przesunięcie akcentów znaczeniowych. Zdanie głoszące, że „cecha dziedziczna to cecha zapisana w genach" przestało być rozumiane, jako zdanie syntetyczne a posteriori (rezultat długiego procesu badań empirycznych), a zaczęło być traktowane jak zdanie analityczne a priori - „cecha dziedziczna to cecha zapisana w genach (ex definitione)"! Skoro tak, wszystkie empirycznie wiarygodne pytania o jakiekolwiek inne kanały dziedziczenia, o dziedziczenie nie-genetyczne, o dziedziczenie szeroko rozumianych cech nabytych, nie mogły być sensownie postawione ${ }^{81}$. Definicja cechy dziedzicznej jako cechy zapisanej $\mathrm{w}$ genach do tej pory pojawia się w słownikach biologii, nawet jeżeli występuje w nich hasło „epigenetyka" ${ }^{82}$. Argument $\mathrm{z}$ wielorakiej realizacji warunków doboru pozwala definitywnie zerwać $\mathrm{z}$ tym sposobem myślenia i bez skrępowania rozważać wspomniane inne kanały jako istotne dla dziedzicznej zmienności, stanowiącej bazę dla selekcji. (Ustalenie realnej wagi tych kanałów dla procesu ewolucji życia na naszej planecie, to kwestia badań empirycznych, a nie analiz filozoficznych; jednak badanie takich „blokad konceptualnych” jak opisana powyżej jest $\mathrm{z}$ pewnością zadaniem filozoficznym). Oczywiście badania epigenetyczne - jak pokazywałem wcześniej - miały znaczenie dla uprawomocnienia tego argumentu. Miały one jednak znaczenie $\mathrm{w}$ sensie historycznym, a nie logicznym. Jak pokazałem w paragrafie 3., możliwość wielorakiej realizacji doboru byłaby zagwarantowana nawet wówczas, gdybyśmy nic nie wiedzieli o innych kanałach przekazywania informacji dziedzicznej.

Podobne „odblokowanie” przynosi teza o wielorakiej realizacji warunków doboru dla analizy problemu poziomów selekcji. Już Lewontin postulował, że „It is important to note a certain generality in the principles. No particular mechanism of inheritance is specified, but only a correlation in fitness between parent and offspring. The population

81 A. Gecow, Ewa, Jabłonka i Lamarck, art. cyt., 30-31.

82 Zob. np. J. Berthet, Dictionnaire de Biologie, Bruxelles 2006, 424, por. 316. 
would evolve whether the correlation between parent and offspring arose from Mendelian, cytoplasmic, or cultural inheritance"s3.

Podobnego zdania był również Endler, który twierdził, że dobór teoretycznie może operować na różnych obiektach: genach, genotypach, populacjach, gatunkach itp., a dziedziczenie może odbywać się na różne sposoby (włączając w to nawet społeczne procesy uczenia się) ${ }^{84}$.

Jednak spojrzenie na dziedziczenie jako wyłącznie przekazywanie genów i sprowadzające gen do roli jedynego „podmiotu selekcji” skutecznie zapobiegało takim spekulacjom. Jak jednak przekonująco argumentował Okasha, abstrakcyjny charakter zasady doboru w połączeniu $\mathrm{z}$ faktem istnienia hierarchii organizacji biologicznej powoduje, że możemy skutecznie rozpatrywać dobór zachodzący na wielu poziomach ${ }^{85}$. Nietrudno zauważyć, że w rozumowaniu Okashy teza o wielorakiej realizacji jest już implicite zawarta. Warto zaznaczyć, że choć współcześnie uważa się, że nawet jeśli dobór na poziomie grup ma znikome znaczenie dla aktualnej ewolucji, to jednak mógł mieć on ważne znaczenie dla ewolucji w przeszłości ${ }^{86}$. Chodzi szczególnie o momenty tzw. wielkich przełomów (major transitions in evolution), w których jednostki zdolne wcześniej do samodzielnego rozmnażania traciły tę zdolność. Przykładem może być powstanie chromosomów, komórek eukariotycznych lub organizmów wielokomórkowych ${ }^{87}$.

83 R.C. Lewontin, art. cyt., 1.

84 J.A. Endler, dz. cyt., 23-26.

85 S. Okasha, dz. cyt., 10-18.

86 Tamże, 17, 218-240. Warto wspomnieć, że Okasha sformułował ciekawy argument przeciw genocentryzmowi, który nie wiąże się bezpośrednio z tezą o wielorakiej realizacji warunków doboru, jednak trudno go w tym miejscu pominąć. Wskazał mianowicie, że podejście genocentryczne nie jest atakowane wyłącznie z pozycji epigenetyki, ale także z pozycji praktyki badawczej biologii ewolucyjnej. Frekwencja genów w populacji jest bowiem zazwyczaj liczona per organizm (a nie np. per komórka!, z których każda zawiera kopię danego genu). Czyni to z organizmu wyróżnioną (do pewnego stopnia) kategorię w biologii ewolucyjnej. Tamże, 159-162.

87 J. Maynard Smith, E. Szathmáry, The Major Transitions in Evolution, dz. cyt., 6-7; J. Maynard Smith, E. Szathmáry, Tajemnice przełomów ewolucji, dz. cyt., 27-31. 


\section{6. ŻYCIE}

Teza o wielorakiej realizacji warunków doboru odgrywa też niebagatelną rolę w analizach dotyczących definicji życia. Problem ten analizowałem już szeroko w innych moich artykułach, tu ograniczę się do podania najważniejszych informacji. Przeprowadzona powyżej analiza wielorakiej realizacji warunków doboru pogłębia moje analizy związane $\mathrm{z}$ definiowaniem życia dokonane w kilku wcześniejszych pracach, w szczególności w artykułach: Wieloraka realizacja $i \dot{z} y c i e$, Is the Nature of Life Unknown?, The Predictions in Evolutionary Biology and Defining of Life oraz Warunki doboru naturalnego a ewolucyjne definicje $\dot{z} y c i a^{88}$.

Poruszając zagadnienie definiowania życia, należy wspomnieć o kilku kluczowych kwestiach. Najpierw trzeba zwrócić uwagę, że definiowanie życia nie jest normalnym zadaniem biologii, a biolodzy mogą skutecznie powiększać wiedzę, nawet o jednostkach, co do których nie są przekonani, czy są żywe (np. wirusach, prionach) ${ }^{89}$. Istnieją jednak obszary, gdzie pytanie o to, czym jest życie, jest ważne. Dotyczy to szczególnie obszarów zainteresowań astrobiologii, badań nad biogenezą (protobiologii), sztucznego życia i biologii syntetycznej. W dziedzinach tych pojawia się problem tego, czy znaleźliśmy/wygenerowaliśmy życie, a także związane z nim problemy, gdzie życia poszukiwać i jak może ono powstawać ${ }^{90}$. Rozważmy raz jeszcze przykład astrobiologii. Szukając alternatywnych form życia poza Ziemią, chcemy wiedzieć czego szukać, a zarazem nie chcemy szukać na ślepo i ślemy nasze sondy badawcze tam, gdzie spodziewamy się, że życie mogło spontanicznie powstać. Co ciekawe, w astrobiologii istnieje swego rodzaju definicyjny

88 Zainteresowanego czytelnika odsyłam do bibliografii na końcu tekstu.

89 M.A. Bedau, Philosophical Aspects of Artificial Life, art. cyt., 496; K. Chodasewicz, Definiować czy nie? Współczesne kontrowersje na temat potrzeby i sposobu definiowania życia, art. cyt., 502.

90 Zob. np. A. Pross, Toward a General Theory of Evolution: Extending Darwinian Theory to Inanimate Matter, Journal of Systems Chemistry 2(2011)1, 1-14. 
klincz. $Z$ jednej strony czołowa światowa agencja kosmiczna - mowa oczywiście o NASA - jako oficjalną posługuje się stworzoną przez Gerarada F. Joyce’a ewolucyjną definicją życia, która głosi, że „życie jest samodpodtrzymującym się systemem chemicznym zdolnym do podlegania darwinowskiej ewolucji” ${ }^{91}$. $Z$ drugiej jednak strony, astrobiolodzy są silnie przywiązani do jakiejś formy biochemicznej definicji życia. Jest ona zakładana raczej implicite, a jej obecność manifestuje się w tym, że poszukiwanie życia poza Ziemią skupia się na poszukiwaniu wody i związków organicznych (typowych dla znanych nam organizmów) ${ }^{92}$. Teza o wielorakiej realizacji warunków doboru zapewnia definicji NASA wolność od tego typu „przedsądów substratowych” i pozwala na skierowanie wyobraźni uczonych na nowe tory. Jak już wspomniałem powyżej, wielu astrobiologów od dawna budowało modele teoretyczne alternatywnych form życia, jednak dyrektywy poszukiwawcze były konserwatywne. Dopiero odkrycie bakterii GFAJ-1 z Jeziora Mono pośrednio inspirowane przez tezę o wielorakiej realizacji ${ }^{3}$ - pozwoliło na świeższe spojrzenie na te modele.

Oczywiście definiowanie życia nie kończy się na definicji NASA ani nawet na grupie ewolucyjnych definicji życia. Jak już zaznaczałem w poprzednich pracach ${ }^{94}$, nawet pozornie skrajnie oddalone od definicji standardowej propozycje - jak choćby niemal równie słynna koncepcja

91 G.F. Joyce, Foreword, w: Origins of Life. The Central Concepts, red. D. Deamer, G.R. Fleischaker, Boston - London 1994, xi (tłumaczenie własne). Więcej na temat tej definicji zob. np. P.L. Luisi. About Various Definitions of Life, art. cyt., 617-618; K. Ruiz-Mirazo, J. Peretó, A. Moreno, An Universal Definition of Life: Autonomy and Open-ended Evolution, Origins of Life and Evolution of Biospheres 34(2004), 327-328.

92 C.F. Chyba, K.P. Hand, Astrobiology: The Study of the Living Universe, Annual Review of Astronomy \& Astrophysics, 43(2005), 34.

93 K. Chodasewicz, Wieloraka realizacja i życie, art. cyt., 129-130.

94 Zob. K. Chodasewicz, Is the Nature of Life Unknown? The Predictions in Evolutionary Biology and Defining of Life, Dialogue\&Universalism (Special Issue: The Philosophy of the Living World), (24)2014(2), 53; Tenże, Ożywione artefakty? Analiza wybranych argumentów przeciwko sztucznemu życiu, art. cyt, 74. 
autopoietyczna Humberto Maturany i Francisco Vareli ${ }^{95}$ - muszą wytłumaczyć się ze stosunku proponowanych kryterialnych własności życia do ewolucji drogą doboru - niezwykle istotnego aspektu świata ożywionego ${ }^{96}$. Innymi słowy: nawet jeśli zakłada się, że ewolucja nie stanowi „esencji” życia, to trudno ją pominąć i należy pokazać, jak np. wynika ona $\mathrm{z}$ bardziej fundamentalnych własności. Koncepcja wielorakiej realizacji życia może być więc niejako przemycona przez założenie o wielorakiej realizacji warunków doboru.

\section{PODSUMOWANIE}

Widać wyraźnie, że teza o wielorakiej realizacji warunków doboru posiada silne umocowanie i liczne konsekwencje. Niekiedy są to konsekwencje o charakterze zwrotnym - tzn. teza jeszcze mocniej inspiruje ścieżki myślenia, które stanowią dla niej umocowanie. Są to: 1) abstrakcyjność zasady doboru, 2) alternatywne formy życia (astrobiologia i Alife), 3) dziedziczenie nie-genetyczne, 4) możliwość wielorakiej realizacji implikowana przez naturę dziedziczenia. Nie mamy tu jednak do czynienia z kolistością argumentacji, gdyż, po pierwsze, argumentacja nie jest liniowa i ma raczej charakter sieci, w której trudno byłoby wyróżnić jedyne „uprzywilejowane” koło, po drugie zaś - możliwość wielorakiej realizacji warunków doboru zostaje zachowana nawet wówczas, gdy pominiemy przesłanki 1) -3) i skupimy się wyłącznie na samej genetyce (4).

Ponowne omawianie wszystkich implikacji analizowanej tezy nie ma w tym miejscu wielkiego sensu. Pozwolę więc sobie powiedzieć o jeszcze jednej konsekwencji tezy o wielorakiej realizacji warunków doboru. Chodzi o jej implikacje metodologiczne dotyczące natury biologii jako

95 Głosi ona, że życie jest systemem autopoietycznym, czyli takim, który posiada wyraźnie wyodrębnioną granicę obejmującą sieć reakcji odtwarzającą wszystkie elementy układu wraz ze wspomnianą granicą. P.L. Luisi, Autopoiesis. A Review and a Reappraisal, art. cyt., 50-52.

96 Tamże, 53-54. Zob. też P.L. Luisi, About Various Definitions of Life, art. cyt., 619-621. 
nauki i jej miejsca wśród innych nauk. Implikacje te wynikają stąd, że problem redukcjonizmu może być analizowany także jako problem metodologiczny. W tym ujęciu możemy zapytywać, czy biologia redukuje się do fizyki i chemii, czy też jest dyscypliną autonomiczną? Jeśli zgodzimy się z tezą, że wymagane przez prawo doboru własności mogą być realizowane przez różne własności fizyczne, to nie sposób oprzeć się tezie, że biologia jest dyscypliną dalece autonomiczną, posiadającą własną dziedzinę wyznaczoną przez zastosowalność praw biologii ewolucyjnej. Teza ta ma rozliczne dalsze konsekwencje - m.in. takie, że dziedzina biologii powinna wykraczać poza zbudowane ze związków organicznych obiekty i ich układy, którymi ta dziedzina zwykle się zajmuje. $Z$ drugiej jednak strony, ponieważ teoria doboru nie determinuje, jakie obiekty mogą pod nią podpadać, jakie mogą one mieć własności i nie określa a priori wartości adaptatywnej określonych cech przedmiotów selekcji ${ }^{97}$, to badania z zakresu bazującej na fizyce i chemii biologii funkcjonalnej zawsze pozostaną niezbędne. Pozwalają one bowiem na odkrywanie i szczegółowe poznanie coraz to nowych cech (z jednej strony m.in. behawioralnych i ekologicznych, a z drugiej m.in. fizjologicznych, anatomicznych i molekularnych) obiektów ożywionych. Bez tej wiedzy szczegółowe analizy ewolucyjne (przewidujące zmiany frekwencji cech w populacji określonych organizmów w danym środowisku) byłyby oczywiście niemożliwe.

\section{BIBLIOGRAFIA}

Barberousse A., Samadi S., Pourquoi et comment formaliser la théorie de l'évolution, w: Les mondes darwiniens. L'évolution de l'évolution, red. T. Heams, P. Huneman, G. Lecointre, M. Silberstein, Éditions Matériologique, Paris 2011, 361-385. Bedau M.A., Philosophical Aspects of Artificial Life, w: Towards a Practice of Autonomous Systems. Proceedings of the First European Conference on Artificial Life, red. P. Bourgine, F.J. Varela, MIT Press, Cambridge 1992, 494-503.

97 L. Nowak, O metodologii Karola Darwina, w: Teoria i metoda w biologii ewolucyjnej, red. K. Łastowski, Poznańskie Studia z Filozofii Humanistyki 7(20), Poznań 2004, 30-32; zob. też C. Emmeche, art. cyt., 467. 
Berthet J., Dictionnaire de Biologie, De Boeck, Bruxelles 2006.

Bouchard F., Ecosystem Evolution is About Variation and Persistence, not Population and Reproduction, Biological Theory 9(2014), 382-391.

Bouchard F., La fitness au-delà des gènes et des organisms, w: Les mondes darwiniens. L'évolution de l'évolution, red. T. Heams, P. Huneman, G. Lecointre, M. Silberstein, Éditions Matériologique, Paris 2011, 417-439.

Bourrat P., From Survivors to Replicators: Evolution by Natural Selection Revisited, Biology\&Philosophy 29(2014), 517-538.

Chodasewicz K., Definiować czy nie? Wspótczesne kontrowersje na temat potrzeby i sposobu definiowania życia, Kosmos. Problemy Nauk Biologicznych 63(2014)4, 501-516.

Chodasewicz K., Evolution, Reproduction and Definition of Life, Theory of Biosciences 133(2014)1, 39-45.

Chodasewicz K., From survivors to minimal reproducers? The need of one more explanation!, w: Philosophy of (the Living) Nature / Filosofia de la Naturaleza Viviente / Философия (живой) природы, red. W. Ługowski, IFiS PAN, Warszawa 2015, 58-65.

Chodasewicz K., Is the Nature of Life Unknown? The Predictions in Evolutionary Biology and Defining of Life, Dialogue\&Universalism (Special Issue: The Philosophy of the Living World) 24(2014)2, 51-61.

Chodasewicz K., Ożywione artefakty? Analiza wybranych argumentów przeciwko sztucznemu życiu, Studia Philosophica Wratislaviensia 10(2015)1, 53-75.

Chodasewicz K., Warunki doboru naturalnego a ewolucyjne definicje życia, Filozofia Nauki 24(2016)1, 41-73.

Chodasewicz K., Wieloraka realizacja i życie, Filozofia i Nauka. Studia filozoficzne i interdyscyplinarne 1(2013), 115-135.

Chyba C.F., Hand K.P., Astrobiology: The Study of the Living Universe, Annual Review of Astronomy\&Astrophysics 43(2005), 31-74.

Clarke E., Plant Individuality: a Solution's to the Demographer's Dilemma, Biology\&Philosophy 27(2012), 321-361.

Cleland C.E., Copley S.D., The Possibility of Alternative Microbial Life on Earth, International Journal of Astrobiology 4(2005)3\&4, 165-173.

Dawkins R., Fenotyp rozszerzony. Dalekosiężny gen, tłum. z ang. J. Gliwicz, Prószyński i S-ka, Warszawa 2003.

Dawkins R., Samolubny gen, tłum. z ang. M. Skoneczny, Prószyński i S-ka, Kraków 2007.

Emmeche C., Life as an Abstract Phenomenon: is Artificial Life Possible?, w: Towards a Practice of Autonomous Systems. Proceedings of the First European Conference 
on Artificial Life, red. P. Bourgine, F.J. Varela, MIT Press, Cambridge 1992, 466-474.

Endler J.A., Natural Selection in the Wild, Princeton University Press, Princeton 1986.

Ferrari F., Szuszkiewicz E., Przedmowa, w: Astrobiologia:poprzezpytkosmiczny do $D N A$, red. F. Ferrari, E. Szuszkiewicz, Wydawnictwo Naukowe Uniwersytetu Szczecińskiego, Szczecin 2006, 5-11.

Fodor J., Special Sciences (or: The Disunity of Science as a Working Hypothesis), Synthese 28(1974), 97-115.

Fodor J. (przy współpracy N. Blocka), Czym nie sq stany psychiczne?, tłum. z ang. T. Baszniak, w: Filozofia umystu, wstęp i wybór B. Chwedeńczuk, Aletheia, Warszawa 1995, 59-82.

Forterre P., Defining Life: The Virus Viewpoint, Origins of Life and Evolution of Biospheres 40(2010), 151-160.

Gecow A., Algorytmy ewolucyjne i genetyczne, ewolucja sieci ztożonych i modele regulacji genowej a mechanizm darwinowski, Kosmos. Problemy Nauk Biologicznych 58(2009)3-4, 429-442.

Gecow A., Ewa, Jabtonka i Lamarck, Kosmos. Problemy Nauk Biologicznych 59(2010)1-2, 27-38.

Gecow A., Informacja dziedziczna i jejkanaty (II odcinekszkicu dedukcyjnej teorii $\dot{z} y$ cia), Filozofia i Nauka. Studia filozoficzne i interdyscyplinarne 2(2014), 351-380.

Godfrey-Smith P., Conditions for Evolution by Natural Selection, Journal of Philosophy 54(2007)10, 489-516.

Godfrey-Smith P., Darwinian Populations and Natural Selection, Oxford University Press, Oxford 2009 (Reprint 2013).

Griffiths P., Philosophy of Biology, w: The Stanford Encyclopedia of Philosophy (Winter 2014 Edition), red. E.N. Zalta, <http://plato.stanford.edu/archives/win2014/ entries/biology-philosophy/>.

Grobler A., Metodologia nauk, Wydawnictwo Aureus, Wydawnictwo Znak, Kraków 2006.

Hang D., Torng E., Orifa C., Schmidt T.M., The effect of natural selection on the performance of maximum parsimony, BMC Evolutionary Biology 7(2007), 94.

Hull D., Individuality and Selection, Annual Review of Ecolology and Systematics 11(1980), 311-332.

Huneman P., Sélection, w: Les mondes darwiniens. L'évolution de l'évolution, red. T. Heams, P. Huneman, G. Lecointre, M. Silberstein, Éditions Matériologique, Paris 2011, 93-144. 
Jablonka E., Lamb M.J., Evolution in Four Dimensions, MIT Press, Cambridge - London 2005.

Jablonka E., Lamb M.J., Transgenerational Epigenetic Inheritance, w: Evolution - the Extended Synthesis, red. M. Pigliucci, G.B. Müller, MIT Press, Cambridge London 2014, 137-174.

Joyce G.F., Foreword, w: Origins of Life. The Central Concepts, red. D. Deamer, G.R. Fleischaker, Jones and Bartlett Publishers, Boston - London 1994, xi-xii. Komosiński M., Sztuczne życie. Algorytmy inspirowane biologicznie, Nauka (2008)4, $7-21$.

Krzanowska H., Zapis informacji genetycznej, w: Zarys mechanizmów ewolucji, red. H. Krzanowska, A. Łomnicki, wyd. 3 zm. i popr., Wydawnictwo Naukowe PWN, Warszawa 2002, 17-72.

Küppers B.-O., Geneza informacji biologicznej. Filozoficzne problemy powstania życia, tłum. z niem. W. Ługowski, PWN, Warszawa 1991.

Lewontin R.C., The Unit of Selection, Annual Review of Ecolology and Systematics 1(1970), 1-18.

Luisi P.L., About Various Definitions of Life, Origins of Life and Evolution of Biospheres 28(1998), 613-622.

Luisi P.L., Autopoiesis. A Review and a Reappraisal, Naturwissenschaften 90(2003), 49-59.

Łastowski K., Dwieście lat idei erwolucji w biologii. Lamarck - Darwin - Wallace, Kosmos. Problemy Nauk Biologicznych, 58(2009)3-4, 257-271.

Łomnicki A., Dobór, dryf i inne czynniki ksztattujace częstość genów, w: Zarys mechanizmów ewolucji, red. H. Krzanowska, A. Łomnicki, wyd. 3 zm. i popr., Wydawnictwo Naukowe PWN, Warszawa 2002,154-214.

Łomnicki A., Spotkanie teorii Darwina z genetykq, Kosmos. Problemy Nauk Biologicznych, 58(2009)3-4, 315-317.

Marino L., Konwergencja ztożonych zdolności poznawczych u waleni i naczelnych, w: Psychologia porównawcza, red. W. Pisula, tłum. z ang. M. Michalski, Academica Wydawnictwo SWPS - Wydawnictwo Naukowe PWN, Warszawa 2006, 93-111.

Maynard Smith J., Problemy biologii, tłum. z ang. M.A. Bitner, PWN, Warszawa 1992.

Maynard Smith J., Szathmáry E., Tajemnice przetomów ewolucji, tłum. z ang. M. Madaliński, PWN, Warszawa 2000.

Maynard Smith J., Szathmáry E., The Major Transitions in Evolution, Oxford University Press, New York 1995. 
Mayr E., To jest biologia. Nauka o świecie ożywionym, tłum. z ang. J. Szacki, Prószyński i S-ka, Warszawa 2002.

Monod J., Le hasard et la nécesité. Essai sur la philosophie naturelle de la biologie moderne, Éditions du Seuil, Paris 1970.

Nowak L., O metodologii Karola Darwina, w: Teoria i metoda w biologii erwolucyjnej, red. K. Eastowski, Poznańskie Studia z Filozofii Humanistyki 7(20), Zysk i S-ka, Poznań 2004, 13-56.

Okasha S., Evolution and the Levels of Selection, Oxford University Press, Oxford 2006 (Reprint 2013).

Pennazio S., Viruses: are they living entities?, Theoretical Biology Forum (Formerly "Rivista di biologia - biology forum«) 2011(1), 45-56.

Pigliucci M., Müller G.B., Elements of an Extended Evolutionary Synthesis, w: Evolution - the Extended Synthesis, red. M. Pigliucci, G.B. Müller, MIT Press, Cambridge - London 2014, 3-17.

Popa R., Between Necessity and Probability: Searching for the Definition and Origin of Life, Springer-Verlag, Berlin - Heidelberg 2004.

Pross A., Toward a General Theory of Evolution: Extending Darwinian Theory to Inanimate Matter, Journal of Systems Chemistry 2(2011)1, 1-14.

Rafiński J., Badanie przebiegu filogenezy, w: Zarys mechanizmów erwolucji, red. H. Krzanowska, A. Łomnicki, wyd. 3 zm. i popr., Wydawnictwo Naukowe PWN, Warszawa 2002, 295-334.

Ridley M., Evolution, Third Edition, Blackwell Publishing, Oxford 2003.

Rosenberg A., McShea D., Philosophy of Biology. A Contemporary Introduction, Routledge, New York - London 2008.

Ruiz-Mirazo K., Peretó J., Moreno A., An Universal Definition of Life: Autonomy and Open-ended Evolution, Origins of Life and Evolution of Biospheres 34(2004), 323-346.

Rzymski P., Poniedziałek B., Czy życie może być oparte na arsenie? Btędy w badaniach nad bakteriami GFAJ-1, Studia Metodologiczne (2013)30, 145-162.

Schultze-Makuch D., Irwin L.N., Life in the Universe. Expectations and Constraints, Springer-Verlag, Berlin - Heidelberg 2008.

Swan L.S., Synthesizing insight: artificial life as thought experimentation in biology, Biology\&Philosophy 24(2009), 687-701.

Urbanek A., Rewolucja naukowa w biologii, Państwowe Wydawnictwo „Wiedza Powszechna”, Warszawa 1973.

Wolfe-Simon F., Blum J.S., Kulp T.R., Gordon G.W., Hoeft S.F., Pett-Ridge J., Stolz J.F., Webb S.M., Weber P.K., Davies P.C.W., Anbar A.D., Oremland R.S., A Bacterium that Can Grow by Using Arsenic Instead of Phosphorus, 
Science (2010), www.scienceexpress.org./2 December 2010/Page 1/10.1126/ science.1197258.

\title{
MULTIPLE REALIZATION OF THE CONDITIONS FOR NATURAL SELECTION AND ITS CONSEQUENCES
}

\begin{abstract}
The text analyzes the problem of the multiple realization of the conditions for natural selection: variation, reproduction and heredity. The main emphasis is placed on the third of these characteristics. The main objective of the analysis is to show that a capacity for multiple realization would exist even if we omit the arguments based on astrobiology and artificial life and focus solely on the analysis of the genetics of known forms of life.

The text also discusses the implications of the multiple realizability thesis for such issues as: reductionism in biology, definition of life, research on epigenetics and the autonomy of biology. The importance of multiple realization for the study of the levels of selection and the major transitions in evolution is also highlighted.
\end{abstract}

Keywords: multiple realization, natural selection, definition of life, reductionism, epigenetics, autonomy of biology

KRZYSZTOF CHODASEWICZ (1982-2016)

Instytut Filozofii i Socjologii PAN, Zespół Filozofii Przyrody

Nowy Świat 72, 00-330 Warszawa

DOI: 10.21697/spch.2017.53.1.11

Niniejszy artykuł powstał w ramach projektu Implikacje wybranych aspektów teorii ewolucji dla problemu definiowania życia. Projekt został sfinansowany ze środków Narodowego Centrum Nauki przyznanych na podstawie decyzji numer DEC-2013/11/D/HS1/04392. 